\title{
Early childhood management on Islamic boarding school
}

\author{
Al Ghazali ${ }^{1}$, Nurhattati fuad ${ }^{2}$, Ma'ruf Akbar ${ }^{3}$ \\ \{alghazali_mp12s3@mahasiswa.unj.ac.id ${ }^{1}$,nurhattati@unj.ac.id², Makrufakbar@unj.ac.id ${ }^{3}$ \}
}

Universitas Negeri Jakarta, Indonesia

\begin{abstract}
This study aims atdeterminingthe management of students which includes planning, organizing, implementing and controlling, as well as results concerning the formation of religion in early childhood of students in the Tarbiyatul Wildan Islamic boarding school. The term "pesantren" which is commonly known among Muslims has been widely discussed and researched by various groups. Pesantren generally accept santri after completing elementary school, or at the age of seven. However, those that accept students or santri from the golden age of 4-6 years are rarely studied. This research employed the qualitative approach. In addition, the data collection techniques were observation, interviews and document studies. Data analysis was performed by reducing, displaying, and deducing data. The results of this study are: the implementation of participant management conducted by the boarding school management has similarities with several theories expressed by experts, although with some weaknesses. In general, the universal management principles such as planning, organizing, actuating and controlling were applied by this pesantren.
\end{abstract}

Keyword: Management, Student, Pesantren, Early childhood

\section{Introduction}

In Islam, equipping children with religious knowledge is an obligation, and among them is being able to read and memorize Alquran. Parents believe that those who have their children memorize the Qur'an will later on the last day get their crown and enter heaven. This therefore encourages them to enroll their children in Islamic boarding schools from as early as the age of 4 . They argue that, "let us part ways temporarily with our children in the world, they will later lead us to forever live together in the hereafter".

A place for boarding santri is better known as pesantren. Manfred ziemek claimed that "Islamic boarding schools are educational institutions which tend not to follow certain patterns, and are personally influenced by their founders and leaders [1]. Culturally, Islamic boarding schools are original Indonesian products as they have been in existence since Islam was introduced into the country, which was long before independence. They are refered to as boarding schools because they are in line with Lisa R. Bass's definition which goes as follows: "a boarding school is defined as a acontrolled residential educational program where students are assigned to structured educational, social and phisycal activities from morning till the end of the day"[2] . 
Their students are called santri in accordance with Arabic books written by salaf scholars in medieval times. These schools have very distinctive characteristics making them easily recognizable in the world of traditional Indonesian education, considering that they are associated with elements like Cabins, mosques, students/santri, Ajengan/Kyai and yellow books[3]. These five basic characteristics clearly describe the nature of pesantren. Islamic boarding school is the oldest educational institutions in Indonesia and is a strategic element in building the lives and strengthening the faith of the children of this nation.

One of these schools is the Tarbiyatul Wildan Islamic Boarding School. It focuses on the implementation of education at the level of early childhood, between 4 and 6 years which is rare in Indonesia and even more uncommon in the world. The main purpose of this pesantren is to educate the generation to memorize Al-quran and planting the akhlaq karimah from an early age. Early childhood education is a process of growth and development of children from the time of birth to six years of age which covers both physical and non-physical aspects by providing stimuli for physical and spiritual development[4]

Richard L. Dorothy defined management as the attainment of organizational goals in an effective and efficient manner through planning, organizing, leading and controlling the organizational resources[5]. It can also be said to be the achievement of these goals effectively and efficiently through planning, organizing, directing, and supervising the resources. Kinicki and Williams suggested[6] that management is the pursuit of organizational goals efficiently and effectively. Organizations and people who collaboratively work towards achieving a specific goal usually place much value on managers due to the multiplier effect.

Student management is required in educational institutions because the students are the subject and object in the process of transforming knowledge and skills. Therefore, attaining success in implementing education will greatly depend on the development of the students' physical, intellectual, social, emotional and psychological potential. Management of students here refers to managing the process of planning, implementing, organizing, and monitoring students so that they are guided from the start to their graduation from school.[7]

\section{Research Method}

The approach used in this study is a qualitative approach that is based on consideration because this research seeks to understand human behavior and experience.Robert K. Yin said[8], qualitative research has five forms, namely:Studying the meaning of people's lives, under realworld condition.Representing the views and perspectives of the people (labeled throught this book, as the participants) in a study.Covering the contextual conditions within which people live, Contributing insight into existing or emerging concepts which may help you explain human social behavior and striving to use multiple sources of evidence rather than relying on a single source. And data collecting uses data analysis: compiling, disassembling, reassembling, interpreting and concluding. The study was conducted from October 2016 to Februari 2018 at pesantren Tarbiyatul Wildan Nihayatul Amal, established in 1992.

The data collected was for identification of management student for early childhood and The purpose of this study is not only to discover the factors that support and inhibit the implementation 
of student management but also to procure solutions to these inhibiting factors. ( see at https://osf.io/rtj7b/ )

\section{Result and discussion}

The managerial stages at the Tarbiyatul Wildan Islamic Boarding School can be described as follows: 1) Fulfilling the objectives that are prioritized by the Tarbiyatul Wildan Islamic Boarding School, namely the acceleration of reading Alquranandirasatis lamiyyah.2) All educational activities are carried out without forgetting the basic rights of students which are playing and socializing with peers. Know that the explanation of the data about the average age of students is between 5-12 years. Students in Tarbiyatul Islamic Boarding School certainly need an atmosphere that accommodates their self-development and this can be achieved through activities that are in accordance with their interests and talents. Therefore, the implementation of all activities with the emotional approach method by the manager is carried out solely to prioritize the will, interest and desire of the santri in fulfilling their self-actualization needs for their psychological development. 3) Making the teaching and learning atmosphereenjoyable and comfortable and thus, making it easier for students to study throughout the day. 4) Making the students pleased and comfortable in the school environment because many small students cry and whine that they want to go home for various reasons. Therefore, the Ustadz strive to make them feel comfortable, calmand happy to be in the school premises [7]. Researchers monitored the efforts made by the administrators to establish the feelings of pleasure and calm, these efforts include creating an exciting learning atmosphere with innovative methods and one that is based on the wishes of the students so that they do not feel pressured and forced. 5) The response towards the management of students at the Tarbiyatul Wildan Islamic Boarding School was positive.

Besides that, it was discovered that some of the obstacles to the success of the school include: firstly, the fact that the learning spirit of students is still unstable. This is common in students that haven't used up to 6 months because they are still in the process of adapting to the new environment, especially in the kindergarten level. Second, it is always difficult for the counselors to make the students comfortable living in the cottage, so it takes time. Third, the diversity in personality of each santri also poses a problem as the students are divided into groups of 7 to 10 students that are different in terms of intellectual abilities, character, interest and talent and they are all guided by 1 religious teacher.Fourthly, it is very challenging for the ustadz to create a pleasant atmosphere for teaching the relatively young students. The fifth problem being faced by the management is that the cleanliness of the environment has not been maximized and the sixth is that while the means for bathing are actually quite good and the quantity of water available is abundant,the problem is that the number of bathrooms is not quite balanced with the number of students.

Based on the results of the research on the implementation of management of students in the Tarbiyatul Wildan Islamic Boarding School, it has not been perfect with 9 Workflows from the implementation of student management conducted by the Tarbiyatul Wildan Islamic Boarding School, namely: 1) quota determination of the capacity of new students; 2) acceptance of new students; 3) orientation for new students;4) grouping of students; 5) individual service for students; 
6) disciplinary measures for students; 7) fostering student activities; 8) release of full study students; 9) coordination of graduates of the school. In connection with the basic concepts conveyed by Richard above, the implementation of student management is as follows:

\subsection{Planning process}

Some management experts including Richard revealed that in management, planning is the beginning of the whole process, before moving on to the next process. A cleric must first prepare a plan carefully. In this case the Tarbiyatul Wildan Islamic Boarding School conducts good planning under the coordination of the central board of directors, the board members of the cottage always hold preparatory meetings early on in the year in order to plan what will be done that year, including the students. The pesantren leaders or pak kyai carry out long-term planning. This can be observed from the interview of the leader who stated that he had made the most obvious long-term plans, first at the initial stages of the establishment of Tarbiyatul Wildan which initially had only a kindergarten division, then the later development to have MI, SMPI, then a Vocational School, followed by teacher training, tutoring and aspiring to establish a college boarding school. All these slowly materialized within 25 years of the establishment of this pesantren in 1992 [8]. According to Richard, several things must be considered from the planning principle [9]. firstly, prepare infrastructure. Secondly, Planning is carried out. Thirdly, the overall manner and model for the application of the plans. Fourthly, an effective and efficient program development must be developed. Fifth, Planning is carried out by not forgetting the readiness of staff who will implement the plan.

\subsection{Organizing process}

The reason for implanting the organizing process is to place people in positions that are suitable for running the organization. As revealed by Richard, Roger said that the main purpose of organizing is to manage human resources in order to achieve satisfactory results in facing problems in the organization. Therefore, managers must play a role in resolving the social and psychological problems being encountered by the employees in their work environment. Achievements in satisfying organizations can organize to survive, and obtain capital support from the government and customers [10].Organizing the management of students in the Tarbiyatul Wildan Islamic Boarding School is carried out through the process of dividing the tasks and choosing the administrators and clerics who will direct the activities of the students. This election is instrumental as it facilitates the occupancy of certain posts such as: a) daily administrators who coordinate directly with the person in charge

In organizing, the Tarbiyatul Wildan Islamic Boarding School applies the same principles as those formulated by management experts with the difference being on the motivation side. Experts state that management can be considered successful depending on the ability of each employee maximize performance so that the a specified goal can be attained. As for Tarbiyatul Wildan Islamic Boarding School, organizing is said to succeed in the similarity of determination to sam'an wa to'atan obey and obey commands of the kiai and fulfill the mandates of the santri guardian, and sincerely solicit the blessings of the Almighty Allah. 


\subsection{Actuating Process}

Actuating or implementation is the carrying out of all the activities planned by the organization including educational organizations. Tarbiyatul Wildan Islamic Boarding School implements organizational activities with the personnel placement that is not only expected expected to implement the concept offered by Richard above, but also to make commitment to the institution, sincerity, dignity and credibility the bases of one's placement to carry out tasks in the institution. Academic skills, social capabilities. The ability to work in a team and to guide is a type of trust in managing santriusia anak.

\subsection{Controlling Process}

Controlling known by supervision aims to identify and examine the organization's running on the plans that have been made. Examination and supervision are considered when determining future organizational policies. In the case of santri management, supervision and examination are a necessity for future program evaluation and planning materials. In addition, the employees would be encouraged to perform better if the clerics provide direction and appreciation for their performances. The method of supervision being applied for the management of students in the Tarbiyatul Wildan Islamic boarding school is similar to Richard's concept in principle. Periodic supervision and inspection is carried out to ensure that everything is going as planned and to be used for reference purposes in the establishment of technical policies in the next period. Surveillance is carried out on a scheduled basis. The one conducted by room care staff and evaluations is held ahead of the increase in volume or level. Generally, the activities in the school are evaluated by teachers in under the leadership of the leaders.

If judging from the effectiveness and efficiency of achieving management goals in the education management study, the system implemented by the Tarbiyatul Wildan Islamic Boarding School in the service of students can be considered successful because it makes use of the four aforementioned basic management processes, namely planning, organizing, selecting and deploying human resources (implementation), and supervision.

\section{Conclusion}

Based on data analysis and discussion of the results of the research that has been stated, the following conclusions were arrived at:

1. The function of court planning in the Karawang Tarbiyatul wildan boarding school has been performed naturally with the planning steps, such as making estimates, formulating goals and programming that is not administratively good.

2. In organizing and recruiting HR, mainly room teachers are not too strict in their criteria. Prioritizing trust for someone who has previously attended the school. 
3. The implementation of santri management which includes the acceptance and selection of santri is considered too easy and there is no minimum standard and standard criterion, for example in the health sector. Extracurricular activities are also minimal as a means of entertainment and development of the potential of santri.

4. The function of santri supervision can be said to be rather loose in matters of security. And coordination with alumni has not been well organized and recorded.

\section{References}

[1] Dhofier, Z. :Tradisi Pesantren Sejarah ,Jakarta: LP3ES. h. 44 (1994)

[2] Daft,N.M.: Potret Dunia Pesantren. Bandung: Humaniora. h.16 (2006)

[3] Richard.L Dorothy Marcic.:Understanding Management $5^{\text {th }}$ edition ( U SA : Thomson South-western, ), h.7. (2006)

[3] Kinicki and Williams.:Management: a Practical Introduction(New York: McGraw-Hill Companies, ), h.4. (2009)

[4] Bateman and Snell.: Management: Leading and Collaborating in a Competitive World(New York: McGraw-Hill Education) h.12 (2015)

[4] Zamakhsyari Dhofier.:Tradisi Pesantren, Studi tentang Pandangan Hidup Kyai (Jakarta: LP3ES, 1990 ), h.18

[5] Manfred ziemek.: Pesantren dalam perubahan sosial,Jakarta: P3Mh. 97 (1985)

[6] Ahmad, K.: Manajemen Pesantren sebagai khazanah tonggak keberhasilan pendidikan islam, ”Jurnal manajemen pendidikan islam Manageria, vol 2,no 1, mei , h.12 (2017)

[7] [8] Robert K. Yin.: Qualitative Research from Star to Finish(New York: The Guilford Press, 2011), h.7.

Dokumentasi video Ceramah KH. MM (2011)

[9] Nanang, F.: Landasan Manajemen Pendidikan (Bandung: Remaja Rosdakarya, 1996), h .49. (1996)

[10] G.R. Terry and L.W.: Rue, Office Management and Control, 18-21

[11] Eka, P.: Manajemen peserta didik, (Bandung: Alfabeta) h.17 (2014)

[12] Roger G. Schroeder.: Operations Management: Decision Making in the Operations Function Hardcover (USA: McGraw-Hill Inc, 1981). 98. (1981) 